Research paper

\title{
Antiparasitic activity, histopathology and physiology of Colossoma macropomum (tambaqui) exposed to the essential oil of Lippia sidoides (Verbenaceae)
}

\author{
Bruna Viana Soares ${ }^{a}$, Lígia Rigôr Neves ${ }^{b}$, Drielly Oliveira Ferreira ${ }^{b}$, \\ Marcos Sidney Brito Oliveira ${ }^{\mathrm{c}}$, Francisco Célio Maia Chaves ${ }^{\mathrm{d}}$, Edsandra Campos Chagas ${ }^{\mathrm{d}}$, \\ Raissa Alves Gonçalves ${ }^{\mathrm{e}}$, Marcos Tavares-Dias ${ }^{\mathrm{a}, \mathrm{b}, *}$ \\ a Programa de Pós-Graduação em Biodiversidade Tropical (PPGBIO), Universidade Federal do Amapá (UNIFAP), Macapá, AP, Brazil \\ ' Embrapa Amapá, Macapá, AP, Brazil \\ c Programa de Pós-Graduação em Recursos Aquáticos Continentais Amazônicos (PPG-RACAM), Universidade do Oeste do Pará (UFOPA), Santarém, PA, Brazil \\ d Embrapa Amazônia Ocidental, Manaus, AM, Brazil \\ e Programa de Pós-Graduação em Aquicultura, Instituto Nacional de Pesquisas da Amazônia (INPA), Manaus, AM, Brazil
}

\section{A R T I C L E I N F O}

\section{Article history:}

Received 10 August 2016

Received in revised form 1 December 2016

Accepted 16 December 2016

\section{Keywords:}

Monogenoidea

Parasites

Medicinal plant

Blood

Tambaqui

\begin{abstract}
A B S T R A C T
In vivo and in vitro antiparasitic activity of the essential oil of Lippia sidoides and blood and histological alterations were assessed in Colossoma macropomum (tambaqui). Essential oil concentrations of 10, 20, 40, 80,160 and $320 \mathrm{mg} / \mathrm{L}$ were assayed in vitro against monogenoideans Anacanthorus spathulatus, Notozothecium janauachensis and Mymarothecium boegeri from fish gills. Lippia sidoides essential oil concentrations of 320 and $160 \mathrm{mg} / \mathrm{L}$ were $100 \%$ effective against monogenoideans in $10 \mathrm{~min}$ and $1 \mathrm{~h}$ of exposure, respectively. However, the effectiveness of $100 \%$ concentrations of $80 \mathrm{mg} / \mathrm{L}$ and $40 \mathrm{mg} / \mathrm{L}$ occurred in 3 and $6 \mathrm{~h}$, respectively. In the in vivo tests, juvenile fish were submitted to $60 \mathrm{~min}$ of baths with $10 \mathrm{mg} / \mathrm{L}$ and $15 \mathrm{~min}$ of baths with $20 \mathrm{mg} / \mathrm{L}$ of the essential oil of $L$. sidoides. These therapeutic baths were not efficient against Ichthyophthirius multifiliis, and monogenoideans present in the gills of $C$. macropomum. In addition, 10 and $20 \mathrm{mg} / \mathrm{L}$ of the essential oil of $L$. sidoides caused an anesthetic effect on the fish and did not influence total glucose and protein plasma levels; however, it decreased the number of total erythrocytes in fish exposed to the higher concentration of this essential oil. Severe alterations and irreversible damage were observed in the fish gills just after $L$. sidoides essential oil baths and after $24 \mathrm{~h}$ of recovery. The most recurrent lesions found were hyperplasia and fusion of the lamellar epithelium, vasodilation, detachment of the gill epithelium and lamellar aneurism, epithelial breakdown with hemorrhage, congestion, edema and necrosis, proliferation of the mucous cells and chloride cells and lamellar hypertrophy. Therefore, since the essential oil of $L$. sidoides has in vitro antiparasitic activity and low concentrations of it have shown toxic effects, the bioactive potential of its main chemical components should be investigated, as well as more efficient forms of its administration in therapeutic baths in order to eliminate fish parasites.
\end{abstract} (C) 2016 Elsevier B.V. All rights reserved.

\section{Introduction}

Medicinal plants have become increasingly popular in aquaculture due to their diversity of chemical components that provide different actions, including therapeutic activity. In fish farming, the search for natural substances with antiparasitic action has

\footnotetext{
* Corresponding author at: Embrapa Amapá, Rodovia Juscelino Kubitschek, km 5 , 2600, 68903-419, Macapá, AP, Brazil.

E-mail addresses: marcos.tavares@embrapa.br, mtavaresdias@pq.cnpq.br (M. Tavares-Dias).
}

gained importance due to their potential effects and because of the damage caused by chemotherapeutic agents, which can damage the environment, fish, and human health. Essential oils extracted from species of Lippia (Verbenaceae) have great bioactive potential, therefore, they could possibly be promising herbal medicines to use in fish farming. Species of Lippia have antimicrobial, antiparasitic, anesthetic, analgesic, anti-inflammatory and antitumor activities (Cunha et al., 2010; Becker et al., 2012; Soares and Tavares-Dias, 2013; Hashimoto et al., 2016; Soares et al., 2016).

Lippia sidoides Cham. 1832, known as alecrim-pimenta, alecrimbravo, estrepa-cavalo and alecrim-grande, is popularly used to treat infections and other diseases, many of which had activities against 
infections proven scientifically (Silva et al., 2006; Lobo et al., 2014; Veras et al., 2014). It is an erect deciduous shrub, much branched and crumbly, typical of the semi-arid vegetation, growing in the Caatinga of the northeast region of Brazil. Leaves are aromatic and spicy, opposite, simple and petiolated. Its flowers are small and whitish, gathered in clusters of short axis in the leaf axils. Its fruits are tiny, producing very small seeds, which rarely germinate (Camurça-Vasconcelos et al., 2007; Fontenelle et al., 2007).

Studies have shown the essential oil of $L$. sidoides have antiparasitic action against ticks (Gomes et al., 2012, 2014), forms of Leishmania (Oliveira et al., 2009; Farias-Júnior et al., 2012), helminths from caprine and ovine animals (Camurça-Vasconcelos et al., 2007) and monogenoideans from Oreochromis niloticus (Hashimoto et al., 2016), and activity against fungi and bacteria (Fabri et al., 2011; Fernandes et al., 2012; Funari et al., 2012; Fontenelle et al., 2007). However, L. sidoides has not been used against monogenoideans from Colossoma macropomum Cuvier, 1818 (tambaqui), an important fish for the fish farming of the region of Amazon.

Colossoma macropomum is a species of Serassalmidae native to Amazon that, due to its rusticity and omnivorous feeding, has been widely cultured in different intensive systems, favoring the dissemination of parasitic diseases because of high densities used in these systems (Dias et al., 2015). As a result, it has often been parasitized by Ichthyophthirius multifiliis (Protozoa), Anacanthorus spathulatus, Notozothecium janauachensis, Mymarothecium boegeri and Linguadactyloides brinkmanni (Monogenoidea), which might cause economic loss (Boijink et al., 2015; Martins et al., 2002; Soares et al., 2016), not yet calculated. Due to the need to efficiently treat these parasites from $C$. macropomum, herbal therapy can be an alternative to chemotherapeutic products (Soares et al., 2016). Thus, because of the bioactive potential of the essential oil (EO) of L. sidoides against different pathogenic agents, it is important to study its action against $C$. macropomum ectoparasites. The objective of this study was to investigate the in vivo and in vitro antiparasitic activity of the EO of $L$. sidoides, and the possible blood and histopathological alterations in the gills of $C$. macropomum.

\section{Materials and methods}

\subsection{Extraction and chemical compounds of the EO of L. sidoides}

The cultivation of $L$. sidoides and the EO extraction were carried out at the Department of Medicinal Plants and Vegetables of Embrapa Western Amazon, in Manaus, State of Amazonas, Brazil. The essential oil was extracted from the leaves and inflorescences of $L$. sidoides by the hydrodistillation technique using a Clevenger apparatus. The chemical analysis of the EO was performed by gas chromatography connected to mass spectrometry. The chemical components of the EO of $L$. sidoides in this study are shown in Table 1.

\subsection{Fish and acclimatization}

The experiments were carried out at the Laboratory of Aquaculture and Fishing of Embrapa Amapá, Macapá, State of Amapá, Brazil. Juveniles of $C$. macropomum $( \pm 30 \mathrm{~g}$ ) were obtained from commercial fish farming. The fish were acclimated during seven days in $500 \mathrm{~L}$ water tanks and fed with fish feed containing 32\% crude protein (CP). In the tanks, the constant system of water renewal was maintained, and the water parameters were monitored: average temperature of $30.7 \pm 0.2^{\circ} \mathrm{C}$, dissolved oxygen of $5.6 \pm 0.4 \mathrm{mg} / \mathrm{L}, \mathrm{pH}$ of $5.3 \pm 0.2$, ammonium of $0.4 \pm 0.2 \mathrm{mg} / \mathrm{L}$, alkalinity of $10.0 \pm 0 \mathrm{mg} / \mathrm{L}$ and hardness of $10.0 \pm 0 \mathrm{mg} / \mathrm{L}$. Removal of organic material accumulated at the bottom of the tanks was daily performed.
Table 1

Chemical constituents of the essential oil of Lippia sidoides.

\begin{tabular}{llll}
\hline Peack & \% content & Retention index & Identification \\
\hline 1 & 1.1 & 854 & (E)-2-hexenal \\
2 & 0.9 & 928 & Alpha-tujeno \\
3 & 2.0 & 989 & Myrcene \\
4 & 1.1 & 1016 & Alpha-terpinene \\
5 & 11.7 & 1024 & p-cimeno \\
6 & 3.6 & 1059 & Gamma-terpinene \\
7 & 1.4 & 1144 & ipsdienol \\
8 & 1.2 & 1175 & -terpineol \\
9 & 1.1 & 1232 & timil-methil-ether \\
10 & 4.6 & 1241 & Carvone \\
11 & 64.5 & 1289 & Thymol \\
12 & 4.9 & 1414 & (E)-Beta-Caryophyllene \\
13 & 1.9 & 1576 & Caryophyllene oxide \\
& Total identified (\%): 100 & \\
\hline
\end{tabular}

\subsection{In vitro assay with the $E O$ of $\mathrm{L}$. sidoides and} monogenoideans from $\mathrm{C}$. macropomum

To assess the exposure time and concentrations of the EO of $L$. sidoides that cause mortality in species of monogenoideans from the gills of 24C. macropomum (15.7 $\pm 1.2 \mathrm{~cm}$ and $78.2 \pm 10.7 \mathrm{~g})$, in vitro assays were performed. In order to do that, two control groups were used, one with tank water and the other with tank water + absolute ethyl alcohol, and six different concentrations of the EO of $L$. sidoides $(10,2040,80,160$ and $320 \mathrm{mg} / \mathrm{L})$, using three replicates for each treatment according to the methodology used by Soares et al. (2016), and in environment temperature of $17-18^{\circ} \mathrm{C}$. This solvent was used in the ratio 1:10.

From the in vitro results, the concentrations used in the therapeutic baths with the EO of $L$. sidoides were determined after a previous test of fish tolerance.

\subsection{In vivo assay with $\mathrm{C}$. macropomum}

Juveniles ( $13.2 \pm 1.1 \mathrm{~cm}$ and $42.4 \pm 10.1 \mathrm{~g}$ ), naturally parasitized, were randomly distributed in 12 tanks of $100 \mathrm{~L}$ in an open water system during $48 \mathrm{~h}$. For this assay, four treatments and three replicates were used with 20 fish for each replicate, and the fish were maintained in a static water system (average temperature of $29.3 \pm 0.1^{\circ} \mathrm{C}$, dissolved oxygen of $6.3 \pm 0.06 \mathrm{mg} / \mathrm{L}$, pH of $5.2 \pm 0.09$, ammonium of $0.3 \pm 0.12 \mathrm{mg} / \mathrm{L}$, alkalinity of $10.0 \pm 0 \mathrm{mg} / \mathrm{L}$ and hardness of $10.0 \pm 0 \mathrm{mg} / \mathrm{L}$ ). The treatments were as follow: control groups with tank water or with water + absolute ethyl alcohol (1:10), the solvent used for diluting the EO, 10 and $20 \mathrm{mg} / \mathrm{L}$ of the EO of $L$. sidoides. The fish submitted to the concentration of $10 \mathrm{mg} / \mathrm{L}$ and $20 \mathrm{mg} / \mathrm{L}$ were exposed to the $L$. sidoides EO bath during 60 and $15 \mathrm{~min}$, respectively, while the fish from the control treatments remained in the bath for $60 \mathrm{~min}$. After the bath time, the tank water was maintained in continuous flow and 10 fish from each replicate, from the different treatments, were used for gill collection, fixed in $5 \%$ formalin, for parasite quantification and identification. The parasites were prepared for identification under the previous recommendations (Eiras et al., 2006). After parasite quantification, prevalence and mean abundance of infection were calculated (Bush et al., 1997). The efficacy of each treatment was calculated according to Zhang et al. (2014).

The other group of fish was used for blood and histopathological analyses.

In vitro concentrations, previously assayed, have shown low fish tolerance to the EO of $L$. sidoides. Thus, only concentrations of 10 and $20 \mathrm{mg} / \mathrm{L}$ could be used in the therapeutic baths for tambaqui. 


\subsection{Analysis procedures of the C. macropomum blood parameters after exposure to the EO of L. sidoides}

After the therapeutic baths of 15 and 60 min with 20 and $10 \mathrm{mg} / \mathrm{L}$ of the EO of $L$. sidoides, respectively, and $60 \mathrm{~min}$ for the control group, five fish from each replicate (15 fish per treatment) were used for blood testing. From each fish, a blood sample was collected by caudal vein puncture, using syringes containing EDTA (10\%), which were divided in two aliquots. An aliquot was used for counting total erythrocytes number in a hemocytometer, determining the hematocrit by using the microhematocrit method and concentration of hemoglobin by using the cyanmethemoglobin method. With the data, Wintrobe's indices were calculated: mean corpuscular volume (MCV) and mean corpuscular hemoglobin concentration (MCHC). Blood smears were prepared and panchromatically stained with a combination of May Grünwald-Giemsa-Wright (Ranzani-Paiva et al., 2013) stains for the leucocyte differential counting up to 200 cells in each blood smear. The identification and classification of the leucocyte populations were made according to the recommendations of Tavares-Dias et al. (1999). The blood smears were also used to count the total number of leucocytes and thrombocytes (Ranzani-Paiva et al., 2013).

The second blood aliquot was centrifuged at $75 \mathrm{G}$ in order to obtain plasma and for the analysis of glucose levels and total plasma proteins. Glucose concentration was determined by the enzymatic colorimetric method of glucose oxidase by using a commercial kit (Biotécnica, MG, Brazil). The concentration of total plasma proteins was determined by the biuret method by using a commercial kit (Biotécnica, MG, Brazil). Both biochemical analyses were read in a spectrophotometer.

\subsection{Procedures of histopathological analyses of the $\mathrm{C}$. macropomum gills after exposure to the EO of L. sidoides}

After the therapeutic baths of 15 and $60 \mathrm{~min}$ with 20 and $10 \mathrm{mg} / \mathrm{L}$ of the EO of $L$. sidoides, respectively, and $60 \mathrm{~min}$ for the control groups, 6 fish from each treatment ( 2 fish per each replicate) were used for the collection of gill arches for histopathological analyses. After $24 \mathrm{~h}$ of these therapeutic baths, other 6 fish per treatment ( 2 fish per each replicate) were used for the collection of gill arches for histopathological analyses (recovery). These fish used in the recovery were kept in continuous flow water tanks and were fed.

The first right gill arch of each fish was collected and fixed in buffered formalin (10\%) for histopathological analyses. The gill arches were dehydrated by a gradual series of ethanol and xylol and, then, embedded in paraffin to obtain successive series of microtome sections. The histological sections were stained with hematoxylin and eosin (HE) and analyzed in a common light microscope (Soares et al., 2016).

The histopathological analysis was performed semi qualitatively using the mean alteration value (MAV) (Schwaiger et al., 1997) and the histopathological alteration index (HAI) (Poleksic and MitrovicTutundzic, 1994).

\subsection{Statistical analyses}

All data were previously assessed based on the assumptions of normality and homoscedasticity by using Shapiro-Wilk and Bartlett tests, respectively. For the data which did not follow any normal distribution pattern, Kruskal-Wallis analysis was used followed by the Tukey test $(\mathrm{p}<0.05)$.

\section{Results}

\subsection{In vitro antiparasitic action of the $E O$ of $\mathrm{L}$. sidoides}

In the in vitro test, the EO of $L$. sidoides has shown $100 \%$ of anthelminthic activity against $A$. spathulatus, $N$. janauachensis and $M$. boegeri (Monogenoidea) from the gills of $C$. macropomum after $10 \mathrm{~min}$ of exposure in the concentration of $320 \mathrm{mg} / \mathrm{L}$, and after 1 and $3 \mathrm{~h}$ of exposure in the concentrations of 160 and $80 \mathrm{mg} / \mathrm{L}$, respectively, when total immobilization of parasites was observed. In the concentration of $40 \mathrm{mg} / \mathrm{L}$, total immobilization of parasites occurred only in $6 \mathrm{~h}$ of in vitro exposure, while in lower concentrations, it occurred after $6 \mathrm{~h}$ of exposure. However, in the fish exposed only to water + alcohol (controls), the beginning of mortality of monogenoideans occurred in $3 \mathrm{~h}$, while the fish exposed only to water from culture tanks (controls), it occurred in a $6 \mathrm{~h}$ of exposure. Total immobilization of parasites in both control groups occurred in more than $8 \mathrm{~h}$ of experiment (Fig. 1 and Table 2).

\subsection{Antiparasitic action after $\mathrm{C}$. macropomum exposure to the EO of L. sidoides}

The fish gills exposed to the EO of $L$. sidoides were parasitized by I. multifiliis, A. spalutathus, $M$. boegeri and $N$. janauachensis, but there were no differences in terms of abundance and prevalence among the different treatments (Table 3 ).

In the therapeutic baths, the fish have shown the following behavior: normal behavior in the control with water, moderate excitement in the control with water + alcohol, lethargy in the concentration of $10 \mathrm{mg} / \mathrm{L}$, and submersion in the bottom of the tanks in the concentration of $20 \mathrm{mg} / \mathrm{L}$. When the continuous flow of water in the tanks was applied, for the elimination of the essential oil, the fish exposed to the EO of $L$. sidoides rapidly returned to normal swimming behavior, and there was no mortality during and after the experiment.

\subsection{Effect of baths with EO of L. sidoides in the blood parameters}

In C. macropomum, $60 \mathrm{~min}$ of baths with $10 \mathrm{mg} / \mathrm{L}$ and $15 \mathrm{~min}$ of baths with $20 \mathrm{mg} / \mathrm{L}$ of the EO of $L$. sidoides did not influence the glucose levels and total plasma proteins. The number of erythrocytes in the fish from the treatment with $20 \mathrm{mg} / \mathrm{L}$ was lower compared to the other treatments, but the hematocrit and hemoglobin of this treatment were similar to the treatments with water and $10 \mathrm{mg} / \mathrm{L}$ of the EO of $L$. sidoides. In relation to the MCV, the treatment with $20 \mathrm{mg} / \mathrm{L}$ of the EO of $L$. sidoides has shown higher values compared to the other treatments, but there was no difference between the values of MCHC (Table 4).

\subsection{Histopathological effects in the C. macropomum gills exposed to the $E O$ of $\mathrm{L}$. sidoides}

After the therapeutic baths, it was observed an increase in the MAV of the fish gills exposed to the EO of L. sidoides in both concentrations used, which were similar to the control with water + alcohol and different from the control with only water from the culture tanks. After $24 \mathrm{~h}$ of recovery, the gill MAV from the concentration of $20 \mathrm{mg} / \mathrm{L}$ was similar to the other treatments, but only the MAV from the concentration of $10 \mathrm{mg} / \mathrm{L}$ was different from the control group with water. A comparison between the two measurements of gill histopathological analyses showed a difference only between the MAV from the fish exposed to $20 \mathrm{mg} / \mathrm{L}$ and the control exposed only to water, after $24 \mathrm{~h}$ of recovery. But, there were similarities between the other treatments in the two periods analyzed (time zero and $24 \mathrm{~h}$ ). 
Table 2

In vitro antiparasitic action of the essential oil of Lippia sidoides against monogenoideans of Colossoma macropomum, in relation to the concentration and time of exposure.

\begin{tabular}{|c|c|c|c|}
\hline Time & Treatments & Mean of live parasites & Mortality (\%) \\
\hline & Water & $25.3 \pm 4.5$ & 0 \\
\hline & Water + alcohol & $22 \pm 2.6$ & 0 \\
\hline & $10 \mathrm{mg} / \mathrm{L}$ & $20 \pm 0.0$ & 0 \\
\hline & $20 \mathrm{mg} / \mathrm{L}$ & $20 \pm 0.0$ & 0 \\
\hline & $40 \mathrm{mg} / \mathrm{L}$ & $21.7 \pm 2.9$ & 0 \\
\hline & $80 \mathrm{mg} / \mathrm{L}$ & $21 \pm 1.7$ & 0 \\
\hline & $160 \mathrm{mg} / \mathrm{L}$ & $20.7 \pm 12$ & 0 \\
\hline \multirow[t]{8}{*}{$0 \mathrm{~h}$} & $320 \mathrm{mg} / \mathrm{L}$ & $20.3 \pm 06$ & 0 \\
\hline & Water & $25.3 \pm 4.5$ & 0 \\
\hline & Water + alcohol & $22.0 \pm 2.6$ & 0 \\
\hline & $10 \mathrm{mg} / \mathrm{L}$ & $20.0 \pm 0.0$ & 0 \\
\hline & $20 \mathrm{mg} / \mathrm{L}$ & $20.0 \pm 0.0$ & 0 \\
\hline & $40 \mathrm{mg} / \mathrm{L}$ & $21.7 \pm 2.9$ & 0 \\
\hline & $80 \mathrm{mg} / \mathrm{L}$ & $19.3 \pm 1.2$ & 8.1 \\
\hline & $160 \mathrm{mg} / \mathrm{L}$ & $8.0 \pm 7.5$ & 61.3 \\
\hline \multirow[t]{8}{*}{$10 \mathrm{~min}$} & $320 \mathrm{mg} / \mathrm{L}$ & $0.0 \pm 0.0$ & 100 \\
\hline & Water & $25.3 \pm 4.5$ & 0 \\
\hline & Water + alcohol & $22.0 \pm 2.6$ & 0 \\
\hline & $10 \mathrm{mg} / \mathrm{L}$ & $20.0 \pm 0.0$ & 0 \\
\hline & $20 \mathrm{mg} / \mathrm{L}$ & $19.7 \pm 0.6$ & 1.5 \\
\hline & $40 \mathrm{mg} / \mathrm{L}$ & $21.3 \pm 3.2$ & 1.8 \\
\hline & $80 \mathrm{mg} / \mathrm{L}$ & $19.3 \pm 1.2$ & 8.1 \\
\hline & $160 \mathrm{mg} / \mathrm{L}$ & $3.3 \pm 3.5$ & 84 \\
\hline \multirow[t]{8}{*}{$20 \mathrm{~min}$} & $320 \mathrm{mg} / \mathrm{L}$ & $0.0 \pm 0.0$ & 100 \\
\hline & Water & $25.3 \pm 4.5$ & 0 \\
\hline & Water + alcohol & $22.0 \pm 2.6$ & 0 \\
\hline & $10 \mathrm{mg} / \mathrm{L}$ & $20.0 \pm 0.0$ & 0 \\
\hline & $20 \mathrm{mg} / \mathrm{L}$ & $19.7 \pm 0.6$ & 1.5 \\
\hline & $40 \mathrm{mg} / \mathrm{L}$ & $21.3 \pm 3.2$ & 1.8 \\
\hline & $80 \mathrm{mg} / \mathrm{L}$ & $19.0 \pm 1.7$ & 9.5 \\
\hline & $160 \mathrm{mg} / \mathrm{L}$ & $2.0 \pm 3.5$ & 90.3 \\
\hline \multirow[t]{8}{*}{$30 \mathrm{~min}$} & $320 \mathrm{mg} / \mathrm{L}$ & $0.0 \pm 0.0$ & 100 \\
\hline & Water & $25.3 \pm 4.5$ & 0 \\
\hline & Water + alcohol & $22.0 \pm 2.6$ & 0 \\
\hline & $10 \mathrm{mg} / \mathrm{L}$ & $18.3 \pm 1.5$ & 8.5 \\
\hline & $20 \mathrm{mg} / \mathrm{L}$ & $19.7 \pm 0.6$ & 1.5 \\
\hline & $40 \mathrm{mg} / \mathrm{L}$ & $21.0 \pm 2.6$ & 3.2 \\
\hline & $80 \mathrm{mg} / \mathrm{L}$ & $16.0 \pm 5.3$ & 23.8 \\
\hline & $160 \mathrm{mg} / \mathrm{L}$ & $0.0 \pm 0.0$ & 100 \\
\hline \multirow[t]{8}{*}{$1 \mathrm{~h}$} & $320 \mathrm{mg} / \mathrm{L}$ & $0.0 \pm 0.0$ & 100 \\
\hline & Water & $25.0 \pm 5.0$ & 1.2 \\
\hline & Water + alcohol & $20.0 \pm 5.0$ & 9.1 \\
\hline & $10 \mathrm{mg} / \mathrm{L}$ & $14.7 \pm 6.8$ & 26.5 \\
\hline & $20 \mathrm{mg} / \mathrm{L}$ & $17.3 \pm 2.1$ & 13.5 \\
\hline & $40 \mathrm{mg} / \mathrm{L}$ & $18.7 \pm 3.1$ & 13.8 \\
\hline & $80 \mathrm{mg} / \mathrm{L}$ & $0.0 \pm 0.0$ & 100 \\
\hline & $160 \mathrm{mg} / \mathrm{L}$ & $0.0 \pm 0.0$ & 100 \\
\hline \multirow[t]{8}{*}{$3 \mathrm{~h}$} & $320 \mathrm{mg} / \mathrm{L}$ & $0.0 \pm 0.0$ & 100 \\
\hline & Water & $4.7 \pm 4.6$ & 81.4 \\
\hline & Water + alcohol & $12.0 \pm 9.5$ & 45.5 \\
\hline & $10 \mathrm{mg} / \mathrm{L}$ & $7.7 \pm 4.9$ & 61.5 \\
\hline & $20 \mathrm{mg} / \mathrm{L}$ & $3.0 \pm 3.6$ & 85 \\
\hline & $40 \mathrm{mg} / \mathrm{L}$ & $0.0 \pm 0.0$ & 100 \\
\hline & $80 \mathrm{mg} / \mathrm{L}$ & $0.0 \pm 0.0$ & 100 \\
\hline & $160 \mathrm{mg} / \mathrm{L}$ & $0.0 \pm 0.0$ & 100 \\
\hline \multirow[t]{8}{*}{$6 \mathrm{~h}$} & $320 \mathrm{mg} / \mathrm{L}$ & $0.0 \pm 0.0$ & 100 \\
\hline & Water & $1.3 \pm 2.3$ & 94.9 \\
\hline & Water+alcohol & $1.3 \pm 1.5$ & 94.1 \\
\hline & $10 \mathrm{mg} / \mathrm{L}$ & $0.0 \pm 0.0$ & 100 \\
\hline & $20 \mathrm{mg} / \mathrm{L}$ & $0.0 \pm 0.0$ & 100 \\
\hline & $40 \mathrm{mg} / \mathrm{L}$ & $0.0 \pm 0.0$ & 100 \\
\hline & $80 \mathrm{mg} / \mathrm{L}$ & $0.0 \pm 0.0$ & 100 \\
\hline & $160 \mathrm{mg} / \mathrm{L}$ & $0.0 \pm 0.0$ & 100 \\
\hline $8 \mathrm{~h}$ & $320 \mathrm{mg} / \mathrm{L}$ & $0.0 \pm 0.0$ & 100 \\
\hline
\end{tabular}

As to the HAI of the gills collected after the therapeutic baths with $10 \mathrm{mg} / \mathrm{L}$ of the EO of L. sidoides, it was similar to the other treatments of the same period, while the concentration of $20 \mathrm{mg} / \mathrm{L}$ was higher to both control treatments. After $24 \mathrm{~h}$ of recovery, the HAI from the treatments with EO was higher in the control group with water and similar to the control group with water + alcohol. A comparison between the two measurements of collection showed both treatments with oil after the bath were similar to both treatments with the EO of $L$. sidoides and control with water + alcohol, after $24 \mathrm{~h}$ of recovery (Table 5 ).

The main histological changes observed in the fish gills exposed to the EO of $L$. sidoides were: hyperplasia and fusion of the lamellar epithelium, vasodilation, detachment of the lamellar epithelium and lamellar aneurism, epithelial breakdown with hemorrhage, congestion, edema and necrosis (Fig. 2A-H), as well as proliferation of the mucous cells and chloride cells and lamellar hypertrophy, changes which occurred less frequently.

\section{Discussion}

The essential oil of $L$. sidoides used in this study presented thymol and $p$-cymene (76.2\%) as major components, similar to what was described by Hashimoto et al. (2016), who found $83.0 \%$ of these two components. However, Veras et al. (2014) reported a higher concentration of thymol $p$-cymene (90.2\%) in the EO of $L$. sidoides analyzed. During the therapeutic baths of $C$. macropomum with the EO of $L$. sidoides, an anesthetic effect was observed, similar to the effect reported on $O$. niloticus when exposed to this essential oil (Hashimoto et al., 2016). Thus, only two low concentrations of this EO could be used in the therapeutic baths for $C$. macropomum. Chemical analysis of natural products is essential, once extracts of the essential oil from the same species of plant can be different due to factors such as location, planting conditions, cut, seasonality, etc. (Soares and Tavares-Dias, 2013). However, since there were no studies about the antiparasitic activity of $L$. sidoides for $C$. macropomum, this has been the first report on it

The in vitro antiparasitic test has shown the concentrations of $40,80,160$ and $320 \mathrm{mg} / \mathrm{L}$ of the EO of L. sidoides had 100\% efficacy against $A$. spatulathus, $M$. boegeri and $N$. janauachensis from C. macropomum, in different time, but lower concentrations compared to these ones had a low efficacy. These results corroborate the findings of Hashimoto et al. (2016), who found 100\% effectiveness in L. sidoides against monogenoideans Cichlidogyrus tilapiae, Cichlidogyrus thurstonae, Cichlidogyrus halli and Scutogyrus longicornis from O. niloticus gills in the concentrations of 160 and $320 \mathrm{mg} / \mathrm{L}$, whose time of parasite sensitivity depended on the concentration of the EO of $L$. sidoides. The essential oil of $L$. sidoides used in these two studies had a similar composition of thymol and p-cymene, substances responsible for the antiparasitic action (Oliveira et al., 2009). In vitro studies of the EO of Lippia alba, whose major components found were carvone and limonene, have shown $100 \%$ of activity against monogenoideans from $C$. macropomum after exposure in concentrations of $160,320,640,1280$ and $2560 \mathrm{mg} / \mathrm{L}$ (Soares et al., 2016).

After in vitro antiparasitic tests, $C$. macropomum were submitted to sensitivity tests with several concentrations of the EO of $L$. sidoides, to determine fish tolerance. The results have indicated a low tolerance of the EO of $L$. sidoides. Thus, only $10-20 \mathrm{mg} / \mathrm{L}$ of this oil could only be used for the $C$. macropomum exposure. As a consequence, there was no difference in the prevalence and abundance of I. multifiliis, A. spatulathus, M. boegeri and N. janauachensis. Hashimoto et al. (2016), after the sensitivity test of $O$. niloticus, the concentration of $20 \mathrm{mg} / \mathrm{L}$ of the EO of $L$. sidoides was adopted for the therapeutic baths and a $33.3 \%$ effectiveness was found against C. tilapiae, C. thurstonae, C. halli and S. longicornis. However, in C. 


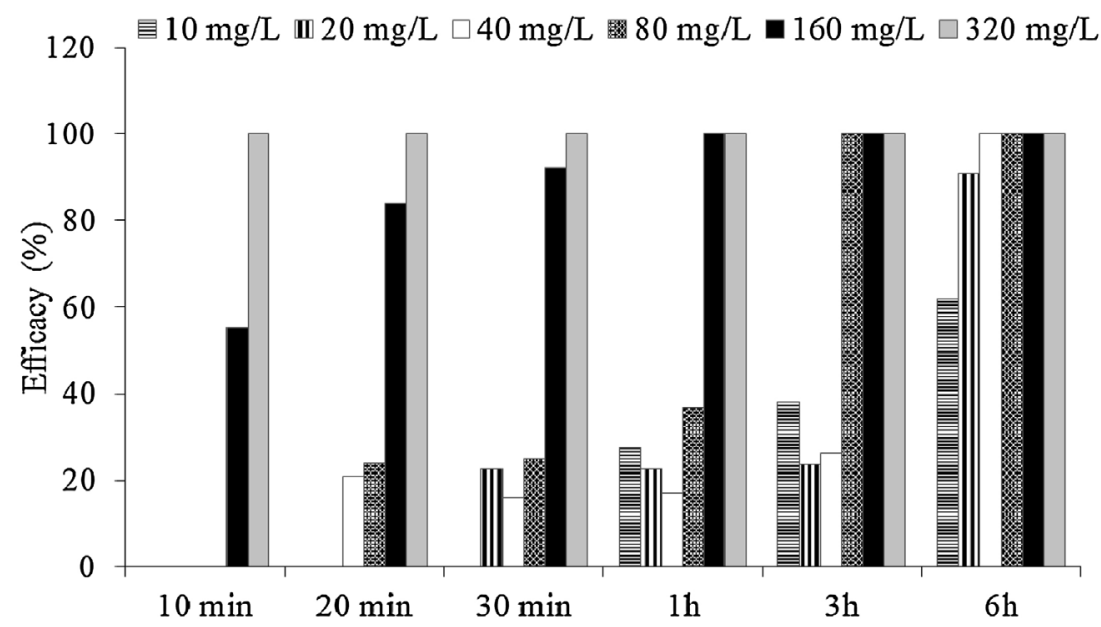

Fig. 1. In vitro efficacy of different concentrations of essential oil of Lippia sidoides against monogenoideans of Colossoma macropomum.

Table 3

Prevalence (P) and mean abundance (MA) of parasites in Colossoma macropomum gills exposure to essential oil of Lippia sidoides.

\begin{tabular}{|c|c|c|c|c|c|c|c|c|}
\hline \multirow[b]{2}{*}{ Parasite species } & \multicolumn{2}{|c|}{$\begin{array}{l}\text { Water }(n=30) \\
60 \text { min }\end{array}$} & \multicolumn{2}{|c|}{$\begin{array}{l}\text { Water + Alcohol }(n=30) \\
60 \text { min }\end{array}$} & \multicolumn{2}{|c|}{$\begin{array}{l}10 \mathrm{mg} / \mathrm{L}(\mathrm{n}=30) \\
60 \mathrm{~min}\end{array}$} & \multicolumn{2}{|c|}{$\begin{array}{l}20 \mathrm{mg} / \mathrm{L}(\mathrm{n}=30) \\
15 \mathrm{~min}\end{array}$} \\
\hline & $\mathrm{P}(\%)$ & MA & $\mathrm{P}(\%)$ & MA & $\mathrm{P}(\%)$ & MA & $\mathrm{P}(\%)$ & MA \\
\hline Ichthyophthirius multifiliis & 100 & $639.1 \pm 561.3^{a}$ & 100 & $451.3 \pm 410.7^{\mathrm{a}}$ & 93.3 & $410.5 \pm 329.3^{a}$ & 96.7 & $469.4 \pm 320.7^{a}$ \\
\hline Anacanthorus spatulathus & 100 & $112.0 \pm 83.0^{\mathrm{a}}$ & 100 & $83.4 \pm 68.8^{\mathrm{a}}$ & 100 & $131.5 \pm 112.9^{\mathrm{a}}$ & 100 & $105.3 \pm 78.2^{\mathrm{a}}$ \\
\hline Mymarothecium boegeri & 83.3 & $16.5 \pm 17.2^{\mathrm{a}}$ & 96.7 & $18.2 \pm 21.8^{\mathrm{a}}$ & 86.7 & $6.6 \pm 6.9^{\mathrm{a}}$ & 86.7 & $11.9 \pm 13.0^{\mathrm{a}}$ \\
\hline Notozothecium janauachensis & 96.7 & $118.2 \pm 91.3^{\mathrm{a}}$ & 100 & $107.0 \pm 73.8^{a}$ & 100 & $151.5 \pm 126.3^{\mathrm{a}}$ & 100 & $119.6 \pm 68.0^{\mathrm{a}}$ \\
\hline
\end{tabular}

Different letters on the same line indicate differences according to the test Tukey $(\mathrm{p}<0.05)$.

Table 4

Blood parameters of Colossoma macropomum submitted to baths with essential oil of Lippia sidoides.

\begin{tabular}{|c|c|c|c|c|}
\hline Parameters & Water & Water+Alcohol & $10 \mathrm{mg} / \mathrm{L}$ & $20 \mathrm{mg} / \mathrm{L}$ \\
\hline Glucose (g/dL) & $67.4 \pm 12.1^{\mathrm{a}}$ & $80.2 \pm 21.0^{\mathrm{a}}$ & $63.7 \pm 15.8^{\mathrm{a}}$ & $64.6 \pm 6.0^{\mathrm{a}}$ \\
\hline Total protein $(\mathrm{mg} / \mathrm{dL})$ & $2.5 \pm 0.4^{\mathrm{a}}$ & $2.4 \pm 0.4^{\mathrm{a}}$ & $2.4 \pm 0.2^{\mathrm{a}}$ & $2.3 \pm 0.4^{\mathrm{a}}$ \\
\hline $\mathrm{RBC}\left(\mathrm{x} 10^{6} / \mu \mathrm{L}\right)$ & $1.3 \pm 0.3^{\mathrm{a}}$ & $1.2 \pm 0.3^{\mathrm{a}}$ & $1.0 \pm 0.15^{\mathrm{a}}$ & $0.6 \pm 0.3^{\mathrm{b}}$ \\
\hline Hemoglobin (g/dL) & $6.9 \pm 0.9^{\mathrm{ab}}$ & $7.0 \pm 0.8^{\mathrm{a}}$ & $5.8 \pm 0.6^{c}$ & $6.2 \pm 0.7^{\mathrm{bc}}$ \\
\hline Hematocrit (\%) & $30.1 \pm 4.9^{\mathrm{ab}}$ & $30.2 \pm 1.7^{\mathrm{a}}$ & $26.5 \pm 2.0^{c}$ & $26.9 \pm 2.8^{b c}$ \\
\hline $\operatorname{MCV}(\mathrm{fL})$ & $278.6 \pm 136.4^{\mathrm{a}}$ & $266.4 \pm 56.3^{a}$ & $267.0 \pm 41.8^{\mathrm{a}}$ & $546.4 \pm 355.8^{\mathrm{b}}$ \\
\hline $\mathrm{MCHC}(\mathrm{g} / \mathrm{dL})$ & $23.2 \pm 3.5^{\mathrm{a}}$ & $23.3 \pm 2.3^{\mathrm{a}}$ & $21.8 \pm 2.2^{\mathrm{a}}$ & $23.2 \pm 2.2^{\mathrm{a}}$ \\
\hline
\end{tabular}

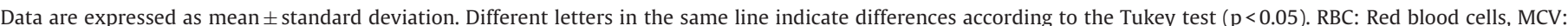
Mean corpuscular volume, MCHC: Mean corpuscular hemoglobin concentration.

Table 5

Mean alteration value (MAV) and histopathological alteration index (HAI) of the gills of Colossoma macropomum exposed to the essential oil of Lippia sidoides.

\begin{tabular}{|c|c|c|c|c|}
\hline \multicolumn{5}{|c|}{ After 30 min therapeutic bath } \\
\hline Treatments & $\mathrm{N}$ & MAV & HAI & Severity of the lesions according to the HAI \\
\hline Water & 6 & $1.0 \pm 0.0^{\mathrm{aAB}}$ & $10.0 \pm 6.3^{\mathrm{aB}}$ & Normal functioning of the gills \\
\hline Water + Alcohol & 6 & $1.8 \pm 0.4^{\mathrm{abAB}}$ & $86.0 \pm 54.8^{\mathrm{cC}}$ & Severe alterations to the gills \\
\hline $10 \mathrm{mg} / \mathrm{L} 60 \mathrm{~min}$ & 6 & $2.0 \pm 0.0^{\mathrm{bAB}}$ & $82.8 \pm 53.1^{\mathrm{abcA}}$ & Severe alterations to the gills \\
\hline $20 \mathrm{mg} / \mathrm{L} 15 \mathrm{~min}$ & 6 & $2.3 \pm 0.5^{\mathrm{bB}}$ & $119.5 \pm 5.4^{\mathrm{bA}}$ & Irreparable damage to the gills \\
\hline \multicolumn{5}{|c|}{ After $24 \mathrm{~h}$ of recovery subsequent to therapeutic bath } \\
\hline Water & 6 & $1.0 \pm 0.0^{\mathrm{bA}}$ & $8.5 \pm 6.1^{\mathrm{aB}}$ & Normal functioning of the gills \\
\hline Water + Alcohol & 6 & $1.7 \pm 0.5^{\mathrm{abAB}}$ & $90.8 \pm 54.2^{\mathrm{abA}}$ & Severe alterations to the gills \\
\hline $10 \mathrm{mg} / \mathrm{L} 60 \mathrm{~min}$ & 6 & $1.8 \pm 0.4^{\mathrm{aAB}}$ & $94.0 \pm 40.0^{\mathrm{bAC}}$ & Severe alterations to the gills \\
\hline $20 \mathrm{mg} / \mathrm{L} 15 \mathrm{~min}$ & 6 & $1.3 \pm 0.5^{\mathrm{abAB}}$ & $96.8 \pm 44.5^{\mathrm{bAC}}$ & Severe alterations to the gills \\
\hline
\end{tabular}

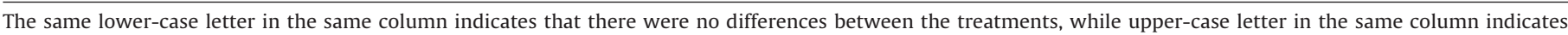
differences between the times, according to the Tukey test $(\mathrm{p}<0.05)$.

macropomum, 100 and $150 \mathrm{mg} / \mathrm{L}$ of the EO of L. alba, during $30 \mathrm{~min}$, showed a efficacy of $40.7 \%$ and $50.3 \%$, respectively, in the treatment against $I$. multifiliis (Soares et al., 2016). Usually, an efficacy $\geq 50 \%$ in reduction of parasitic intensity is considered acceptable
(Sommerville et al., 2016); however, we accept only an efficacy $\geq 70 \%$.

Fish gills are organs responsible for the breathing, osmoregulation and excretion in fish (Fiuza et al., 2011; Kumar et al., 2010), 

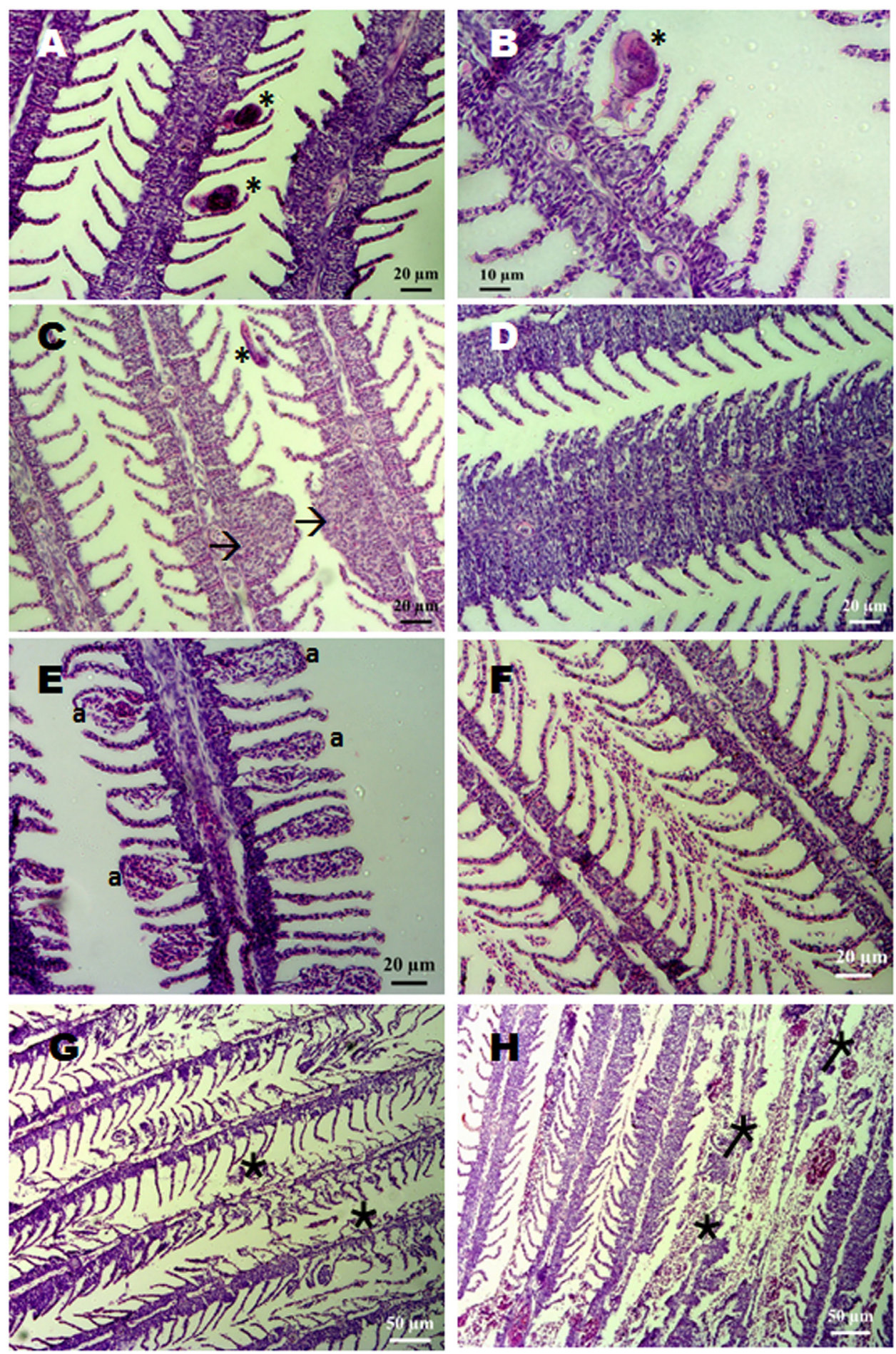

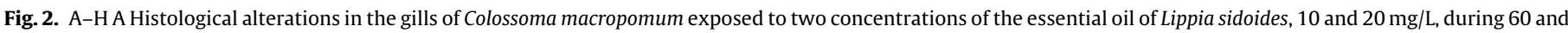

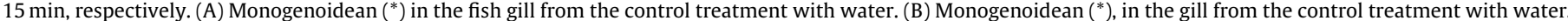

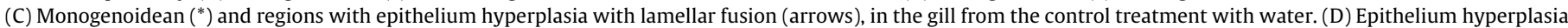

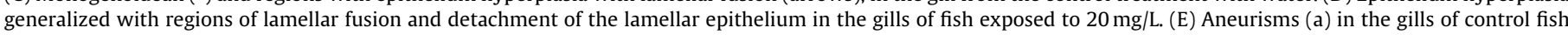

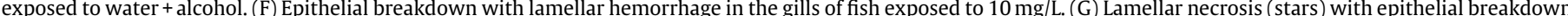

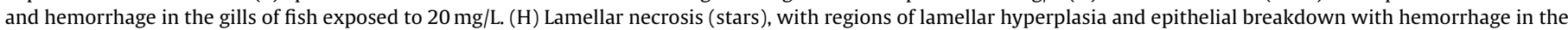
gills of fish exposed to $20 \mathrm{mg} / \mathrm{L}$.

thus, they respond to exposure of different natural compounds. In C. macropomum, the results of the histological analysis have shown the therapeutic baths from the treatments with water+alcohol, 10 and concentration of $20 \mathrm{mg} / \mathrm{L}$ of the EO of L. sidoides caused severe alterations in the gills, such as hyperplasia and fusion of the lamellar gill epithelium, vasodilation, detachment of the lamellar epithelium and lamellar aneurism, epithelial breakdown with hemorrhage, congestion, edema and necrosis. Similar studies with therapeutic baths with concentrations of 100 and $150 \mathrm{mg} / \mathrm{L} \mathrm{of} L$. alba have also observed severe alterations in the fish gills, caused 
by the alcohol of the EO (Soares et al., 2016). Veras et al. (2014) reported thymol and $p$-cymene to possess topic anti-inflammatory activity, but prolonged use of this EO causes inflammatory effect. Oliveira et al. (2014), evaluating the cutaneous inflammatory action of the EO of L. sidoides in mice, observed this oil caused an increase in skin thickness, edema and cutaneous erythema in various levels in mice, and its effect being dose-dependent, but there was no delay in wound healing. In addition, there was a cytotoxic effect on monocytic cells exposed to $100 \mu \mathrm{g} / \mathrm{mL}$ of the EO of $L$. sidoides and only $57.8 \%$ of the cells were viable after exposure (Rondon et al., 2012).

The therapeutic baths with concentrations of 10 and $20 \mathrm{mg} / \mathrm{L}$ of the EO of $L$. sidoides did not influence the glucose levels and total plasma proteins, but the MCV increased because of a decrease in the number of erythrocytes, hematocrit and hemoglobin in the fish exposed to $20 \mathrm{mg} / \mathrm{L}$. Such decrease in the number of erythrocytes, hemoglobin and hematocrit can be related to hemorrhagic gill lesions, once in the treatments with the EO of L. sidoides the HAI varied, with severe injury in the gills to and irreparable injury. Similar results in blood parameters and gill injuries also occurred in C. macropomum exposed to concentrations of 100 and $150 \mathrm{mg} / \mathrm{L}$ of the EO of $L$. alba, during therapeutic baths of $30 \mathrm{~min}$ (Soares et al., 2016). Therefore, as the EOs of Lippia spp. can cause gill lesions and alterations in blood parameters in fish, they should not be used sparingly in therapeutic baths.

The control group using water + alcohol differed from the control group using tank water only as to gill lesions, because the alcohol used as a solvent of the essential oil can influence in the results. Colossoma macropomum exposed to water + alcohol has shown severe alterations in the gills, while the fish exposed to water only did not present functional alterations in the gills. Other studies have also shown the influence of different solvents, such as alcohol (Soares et al., 2016), DMSO (Hashimoto et al., 2016) and Tween-80 (Steverding et al., 2005) in experimental studies about antiparasitic activity using plant extracts. Therefore, such solvents can potentialize the action of the essential oils used in therapeutic baths.

\section{Conclusions}

In vitro efficacy of the essential oil of $L$. sidoides was dosedependent and even the low concentrations used in the therapeutic baths showed toxicity, causing histopathological alterations. In addition to that, the solvent used in the essential oil causes damage to the fish gills, resulting in blood and histological alterations, without satisfactory tissue recovery in $24 \mathrm{~h}$. Therefore, the concentrations of the essential oil of $L$. sidoides and the exposure time used in this study cannot be indicated in the antiparasitic treatment against $I$. multifiliis and monogenoideans from C. macropomum yet. However, herbal therapy is an alternative therapeutic resource in fish farming, but studies to evaluate the bioactivity of the major compounds of the essential oil of $L$. sidoides should be conducted, besides testing more efficient forms of administration in fish.

\section{Acknowledgments}

The authors herein thank the Conselho Nacional de Desenvolvimento Científico e Tecnológico (CNPq) for the financial support (\#472054/2013-9) and for the PQ scholarship granted on Dr. M. Tavares-Dias (\#375930/2015-9).

\section{References}

Becker, A.G., Parodi, T.V., Heldwein, C.G., Zeppenfeld, C.C., Heinzmann, B.M., Baldisserotto, B., 2012. Transportation of silver catfish, Rhamdia quelen, in water with eugenol and the essential oil of Lippia alba. Fish Physiol. Biochem. 38, 789-796.

Boijink, C.L., Miranda, W.S.C., Chagas, E.C., Dairiki, J.K., Inoue, L.A.K.A., 2015. Anthelmintic activity of eugenol in tambaquis with monogenean gill infection. Aquaculture 438, 138-140.

Bush, A.O., Lafferty, K.D., Lotz, J.M., Shostack, A.W., 1997. Parasitology meets ecology on its own terms: Margolis et al. revisited. J. Parasitol. 83 (4), 575-583.

Camurça-Vasconcelos, A.L.F., Bevilaqua, C.M.L., Morais, S.M., Maciel, M.V., Costa, C.T.C., Macedo, I.T.F., Oliveira, L.M.B., 2007. Anthelmintic activity of Croton zehntneri and Lippia sidoides essential oils. Vet. Parasitol. 148, 288-294.

Cunha, M.A., Barros, F.M.C., Garcia, L.O., Veeck, A.P.L., Heinzmann, B.M., Loro, V.L., Emanuelli, T., Baldisserotto, B., 2010. Essential oil of Lippia alba: a new anesthetic for silver catfish, Rhamdia quelen. Aquaculture 306, 403-406.

Dias, M.K.R., Neves, L.R., Marinho, R.G.B., Tavares-Dias, M., 2015. Parasitic infections in tambaqui from eight fish farms in Northern Brazil. Arq. Brasil. Med. Vet. Zoot. 67 (4), 1070-1076.

Eiras, J.C., Takemoto, R.M., Pavanelli, G.C., 2006. Métodos de estudos e técnicas laboratoriais em parasitologia de peixes. Editora UEM, Maringá, 173 pp.

Fabri, R.L., Nogueira, M.S., Moreira, J.R., Bouzada, M.L.M., Scio, E., 2011. Identification of antioxidant and antimicrobial compounds of Lippia species by bioautography. J. Med. Food 14 (7/8), 840-846.

Farias-Júnior, P.A., Rios, M.C., Moura, T.A., Almeida, R.P., Alves, P.B., Blank, A.F., Fernandes, R.P.M., Scher, R., 2012. Leishmanicidal activity of carvacrol-rich essential oil from Lippia sidoides Cham. Biol. Res. 45, 399-402.

Fernandes, L.P., Candido, R.C., Oliveira, W., 2012. Spray drying microencapsulation of Lippia sidoides extracts in carbohydrate blends. Food Bioprod. Proc. 90, 425-432.

Fiuza, T.S., Silva, P.C., Paula, J.R., Tresvenzol, L.M.F., Souto, M.E.D., Sabóia-Morais, S.M.T., 2011. Análise tecidual e celular das brânquias de Oreochromis niloticus L. tratadas com extrato etanólico bruto e frações das folhas da pitanga (Eugenia uniflora L.) -Myrtaceae. Rev. Brasil Plantas Med. 13 (4), 389-395.

Fontenelle, R.O.S., Morais, S.M., Brito, E.H.S., Kerntopf, M.R., Brilhante, R.S.N., Cordeiro, R.A., Tomé, A.R., Queiroz, M.G.R., Nascimento, N.R.F., Sidrim, J.J.C., Rocha, M.F.G., 2007. Chemical composition, toxicological aspects and antifungal activity of essential oil from Lippia sidoides Cham. J. Antimicrob. Chemother. 59, 934-940.

Funari, C.S.F., Gullo, P., Napolitano, A., Carneiro, R.L., Mendes-Giannini, M.J.S., Fusco-Almeida, A.M., Piacente, S., Pizza, C., Silva, D.H.S., 2012. Chemical and antifungal investigations of six Lippia species (Verbenaceae) from Brazil. Food Chem. 135, 2086-2094.

Gomes, G.A., Monteiro, C.M.O., Senra, T.O.S., Zeringota, V., Calmon, F., Matos, R.S., Daemon, E., Gois, R.W.S., Santiago, G.M.P., Carvalho, M.G., 2012. Chemical composition and acaricidal activity of essential oil from Lippia sidoides on larvae of Dermacentor nitens (Acari: Ixodidae) and larvae and engorged females of Rhipicephalus microplus (Acari: Ixodidae). Parasitol. Res. 111, 2423-2430.

Gomes, G.A., Monteiro, C.M.O., Julião, L.S., Maturano, R., Senra, T.O.S., Zeringóta, V. Calmon, F., Matos, R.S., Daemon, E., Carvalho, M.G., 2014. Acaricidal activity of essential oil from Lippia sidoides on unengorged larvae and nymphs of Rhipicephalus sanguineus (Acari: Ixodidae) and Amblyomma cajennense (Acari: Ixodidae). Exp. Parasitol. 137, 41-45.

Hashimoto, G.S.O., Neto, F.M., Ruiz, M.L., Achille, M., Chagas, E.C., Chaves, F.C.M., Martins, M.L., 2016. Essential oils of Lippia sidoides and Mentha piperita against monogenean parasites and their influence on the hematology of Nile tilapia. Aquaculture 450, 182-186.

Kumar, A., Prasad, M.R., Srivastava, K., Tripathi, S., Srivastav, A.K., 2010. Branchial histopathological study of catfish Heteropneustes fossilis following exposure to purified neem extract, azadirachtin. World J. Zool. 5 (4), 239-243.

Lobo, P.L.D., Fonteles, C.S.R., Marques, L.A.R.V., Jamacaru, F.V.F., Fonseca, S.G.C., Carvalho, C.B.M., Moraes, M.E.A., 2014. The efficacy of three formulations of Lippia sidoides Cham. essential oil in the reduction of salivary Streptococcus mutans in children withcaries: a randomized double-blind, controlled study. Phytomedicine 21, 1043-1047.

Martins, M.L., Moraes, F.R., Fujimoto, R.Y., Nomura, D.T., Fenerick Jr., J., 2002. Respostas do híbrido tambacu (Piaractus mesopotamicus Holmberg, 1887 macho X Colossoma macropomum Cuvier, 1818 fêmea) a estímulos simples ou consecutivos de captura. Bol. Inst. Pesca 28 (2), 195-204.

Oliveira, V.C.S., Moura, D.M.S., Lopes, J.A.D., Andrade, P.P., Silva, N.H., Figueiredo, C.B.Q., 2009. Effects of essential oils from Cymbopogon citratus (DC) Stapf., Lippia sidoides Cham., and Ocimum gratissimum L. on growth and ultrastructure of Leishmania chagasi promastigotes. Parasitol. Res. 104, 1053-1059.

Oliveira, M.L.M., Bezerra, B.M.O., Leite, L.O., Girão, V.C.C., Nunes-Pinheiro, D.C.S 2014. Topical continuous use of Lippia sidoides Cham. essential oil induces cutaneous inflammatory response, but does not delay wound healing process. J. Ethnopharmacol. 153, 283-289.

Poleksic, V., Mitrovic-Tutundzic, V., 1994. Fish gills as a monitor of sublethal and chronic effects of pollution. In: Muller, R., Lloyd, R. (Eds.), Sublethal and Chronic Effects of Pollutants on Freshwater Fish. Fishing News Books, Oxford, pp. 339-352.

Ranzani-Paiva, M.J.T., Padua, S.B., Tavares-Dias, M., Egami, M.I., 2013. Métodos para análises hematológicas em peixes. EDUEM, Maringá, 135 pp.

Rondon, F.C.M., Bevilaqua, C.M.L., Accioly, M.P., Morais, S.M., Andrade-Júnior, H.F., Carvalho, C.A., Lima, J.C., Magalhães, H.C.R., 2012. In vitro efficacy of Coriandrum sativum, Lippia sidoides and Copaifera reticulata against Leishmania chagasi. Rev. Brasil. Parasitol. Vet. 21 (3), 185-191. 
Schwaiger, J., Wanke, R., Adam, S., Pawert, M., Honnen, W., Triebskorn, R., 1997. The use of histopathological indicators to evaluate contaminant-related stress in fish. J. Aquat. Ecosyst. Stress Recov. 6, 75-86.

Silva, M.I., Gondim, A.P.S., Nunes, I.F.S., Sousa, F.C.F., 2006. Utilização de fitoterápicos nas unidades básicas de atenção à saúde da família no município de Maracanaú (CE). Rev. Bras. Farmacogn. 16 (4), 455-462.

Soares, B.V., Tavares-Dias, M., 2013. Espécies de Lippia (Verbenaceae), seu potencial bioativo e importância na medicina veterinária e aquicultura. Biota Amaz. 3 (1), 109-123.

Soares, B.V., Neves, L.R., Oliveira, M.S.B., Chaves, F.C.M., Dias, M.K.R., Chagas, E.C., Tavares-Dias, M., 2016. Antiparasitic activity of the essential oil of Lippia alba on ectoparasites of Colossoma macropomum (tambaqui) and its physiological and histopathological effects. Aquaculture 452, 107-114.

Sommerville, C., Endris, R., Bell, T.A., Ogawa, K., Buchmann, K., Sweeney, D., 2016. World association for the advancement of veterinary parasitology (WAAVP) guideline for testing the efficacy of ectoparasiticides for fish. Vet. Parasitol. 219, 84-99.
Steverding, D., Morgan, E., Tkacynski Walder, F., Tinsley, R., 2005. Effect of Australian tea tree oil on Gyrodactylus spp.: infection of the three-spined stickleback Gasterosteus aculeatus. Dis. Aquat. Org. 66, 29-32.

Tavares-Dias, M., Sandrin, E.F.S., Campos Filho, E., 1999. Características hematológicas do tambaqui Colossoma macropomum Cuvier (Osteichthyes: Characidae) em sistema de monocultivo intensivo. II. Leucócitos. Rev. Brasil. Zool. 16, 175-184.

Veras, H.N.H., Rodrigues, F.F.G., Botelho, M.A., Menezes, I.R.A., Coutinho, H.D.M., Costa da, L.G.M., 2014. Antimicrobial Effect of Lippia sidoides and thymol on Enterococcus faecalis biofilm of the bacterium isolated from Root Canals. Sci. World J., http://dx.doi.org/10.1155/2014/471580.

Zhang, X.P., Li, W.X., Ai, T.S., Zou, H., Wu, S.G., Wang, G.T., 2014. The efficacy of four common anthelmintic drugs and traditional Chinese medicinal plant extracts to control Dactylogyrus vastator (Monogenea). Aquaculture 420-421, 302-307. 